\title{
BUSINESS IMPROVEMENT DISTRICTS AS A MANAGEMENT INSTRUMENT FOR CITY CENTER'S REGENERATION IN SERBIA
}

\author{
UDC 711.523(497.11); 711.4-168(497.11)
}

\section{Uroš Radosavljević, Aleksandra Đorđević, Jelena Živković}

Faculty of Architecture, University of Belgrade, Serbia

\begin{abstract}
Urban regeneration and economic development in the context of competitive global markets and impacts to Serbian cities represent challenges calling for new responses for transformative action in urban governance. Policy-makers understanding of that relation may contribute to suitable use of policy instruments for creating good business environment in cites. Business improvement districts (BIDs) represent possible model used as a management instrument for fostering local economic development, city promotion and improving the quality of urban public space and life. The paper presents theoretical approaches of policy instruments use and sets recommendations for management of BIDs based on two cases of city center's regeneration in Serbia. We argue that for BIDs to be a useful model for city center's regeneration, an appropriate use and combination of regulatory, economic and informational management instruments is necessary.
\end{abstract}

Key words: Business improvement districts, management instruments, urban regeneration

\section{INTRODUCTION}

Fundamental changes in society in general, such as globalization and transformation towards information and network society [1], as well as transition processes from the socialist centrally planned to the market economy in Serbia in particular [2], require innovative strategies for cities to get organized in order to strengthen competitive position and create good business environment and promotion of local areas to attract new business [3]. Globalization influences the relative importance and the role of the national state in the process of decentralization to regional and local levels of government [4]. Roles and power relations between various levels of government are becoming more complex in a context of economic restructuring. Traditional roles and relations between

Received March 10, 2015 / Accepted April 22, 2015

Corresponding author: Uroš Radosavljević, University of Belgrade, Faculty of Architecture,11000 Belgrade, Bulevar kralja Aleksandra br. 73/II, Serbia

E-mail: yros@arh.bg.ac.rs 
public and private sector are changing in governance and city building processes. The role of private sector, whether big or small and medium enterprises (SME), is increasing in the realization of own interests in particular projects as well as influencing creation of public urban policies [2]. These trends influence different ways of urban management and use of different policy instruments in European cities from 1980s. New models and instruments for transformative action in urban governance are needed, which take into consideration the logic and functioning of markets on global competitive level and sustainable, economic and social impacts for the locality. BIDs represent possible model usually used as a management instrument for fostering local economic development, city promotion and improving the quality of urban public space and life. BID models may enable further development of existing companies, create a favorable business environment for support to enterprises, and growth of trust among different actors in business sector along with customers and local residents.

\section{Methodology}

The aim of this paper is to investigate the possibilities of applying the BID model for the regeneration of Serbian city centers. Conceptual framework has been drawn on the theoretical level using concepts of governance and management and Vedung's [5] minimalist policy instruments approach relating them to BID models in our research. Using case study methodology at the empirical level we have analyzed two Serbian BID examples with positive and negative effects, the type of actors involved and applied management instruments. Zrenjanin was chosen as the first city that implemented BID, which served as a pilot project and benchmark for other BIDs in Serbia. Vranje was the first city to implement BID model in indoor space. For the Zrenjanin case implemented in 2003 we used published documents which served as guidelines for other Serbian cities implementing BID. Main data source for the Vranje case was based on field observations and interviews with main BID stakeholders. Comparative analysis was done for the evaluation of cases in order to define main aspects, success or failure factors and conditions in order to define recommendations for planning, management, design and implementation of BIDs in Serbia.

\section{URban GOVERnANCE, MANAGEMENT \& POLICY INSTRUMENTS FOR BID}

Social science and public policy debate in Europe focuses on the changing urban governance modes from the mid 1980s, with generally accepted reasons: a new policy of European integration, the impacts of globalization on the relative importance of the nation state to sub national regional and local levels of government, the dynamics of local economies in the context of shift from Fordist to post-Fordist production, changes in the patterns of social welfare distribution and changes in social expectations of creating social policy and implementation of policy instruments [4]. In such a context, the implications of effects of broader economic, political and institutional transformation at the global and national levels contribute to shift towards entrepreneurial urban governance at the local level in which cities use different strategies to attract private investment for strengthening competitive position [3]. Healey emphasizes institutional governance processes for 
mobilization of social action focusing on finding political and institutional instruments in response to specific problems present in a particular context [4]. Additionally, new public management and governance approaches have emerged from the mid 1990s in the field of political studies as an alternative to bureaucratic public administration due to the growing complexity in policy making, implementation and provision of services [6]. According to Bovaird \& Löffler [7] new public management focus on politically formulated goals with effectiveness, efficiency and measurable results in the provision of public services, leaving implementation to public or private organizations, while governance stresses collaboration processes among interdependent actors with goals not known in advance, regardless of the outcomes achieved. Better understanding of the relation of governance and functioning of markets may contribute to policy-makers deeper insight into the ways in which individual and combined policy instruments affect the achievement of socioeconomic objectives and outcomes, such as sustainability, equality, social justice [8]. Fainstein raises the question how urban governments actually stimulate private sector to invest through public policies and programs [9]. We extend this issue to our research question: what is an appropriate combination of policy instruments in a specific Serbian context for keeping or attracting businesses in the city center's regeneration processes? Vedung argues that a unique mix of several policy instruments and choosing the appropriate combination is one of the most difficult and important issues in strategic political planning and conceptualizes policy instruments as regulations, economic means, and information [5]. Vedung explains that "regulations are measures undertaken by governmental units to influence people by means of [...] rules and directives [...] to act in accordance with what is ordered [...]. Economic instruments involve either the handing out or the taking away of material resources [...]. Information [...] covers attempts at influencing people through the transfer of knowledge, the communication of reasoned argument, and persuasion" [5] (p. 51). Relation and basic possibilities between governor and governed in the typology of policy instruments are shown in table 1 .

Table 1 Policy instruments - relation between governor and governed, based on Vedung

[5] (p. 31)

\begin{tabular}{lcc}
\hline Type of policy instrument & Relationship & Possibilities \\
\hline Regulations & Obligatory & Rules and directives \\
Economic means & $\begin{array}{c}\text { Not obligated } \\
\text { Easier or difficult to } \\
\text { perform action }\end{array}$ & Material resources \\
& Persuasive/ & No material resources \\
Information & communication & Not obligatory \\
& & directives \\
\hline
\end{tabular}

\subsection{Characteristics and purpose of the BID model}

In relation to the contemporary policy and management instruments, BIDs are important because of the logic of competitiveness among cities which requires entrepreneurial forms of 
governance. BIDs are efficient due to fast decision-making, they are usually based on public-private partnerships, and they create a positive environment for new and small businesses. BID complements its activities to public services and improves management of spatially clustered shopping and business areas. BID organization is based on the self-help doctrine, enabling own funding and long-term operations through the mechanisms of selftaxation regulated by municipal decisions [10]. BIDs are trying to attract more visitors, investors and sales through the creation of attractive public space, while increasing own competitiveness in relation to traditional shopping malls [11]. Founders of the BID are shop owners, entrepreneurs and residents which recognized the concept while living and working in the area. Local municipalities can also be founders of the BID. This concept originates from the 1960s when a small group of businessmen and shop owners in Toronto invented a new model for cooperation contributing to the revitalization of the area [12]. It is usually stated that the BID is an instrument used in the old city centers and the main reason for its widespread acceptance is the ability to adapt to local conditions [13]. BID models might solve problems of maintenance, security, accessibility and parking in areas. Although some of these problems are the competence of the public utility companies, the founders of BID want their area to be better regulated, allowing them indirect benefits through higher turnover and visit. Other benefits are the crime reduction and increase in property values in the area [14] (Ellen, Schwartz, \& Voicu, 2007). BID is also an important tool of city promotion, improvement of the quality of public life and blurring the boundaries between private and public space. BID may resolve specific local problems contributing to more efficient and effective urban governance [15]. However, BIDs are criticized for nondemocratic orientation related to the power of private sector to manage use and look of public space [11], that evaluation of results is absent, and that by improvement in that specific area inequalities are created compared to other areas in the city.

\section{BID MODEL FOR THE REGENERATION OF CITY CENTERS IN SERBIA}

BIDs were introduced in Serbia in 2002 as the part of the Program for Local Government Reform (SLGRP) and the Community Revitalization through Democratic Action (CRDA), funded by the United States Agency for International Development (USAID) with the aim of increasing the participation of citizens and businesses in urban governance and improvement of trade and business zones in Serbian cities [10]. A unique feature of the program in Serbia was an agreement signed between pilot municipalities and the USAID for the equal share of costs during physical reconstruction of BID (Fig. 1). However, merchants and property owners are responsible for the BID association funding, maintenance and quality of public space, and organization of promotional activities. The expected outcome was cooperation between the city and retailers, entrepreneurs and property owners. However, formation and duration of BID, association's management responsibilities, monitoring and evaluation process are not regulated by legislation in Serbia. 


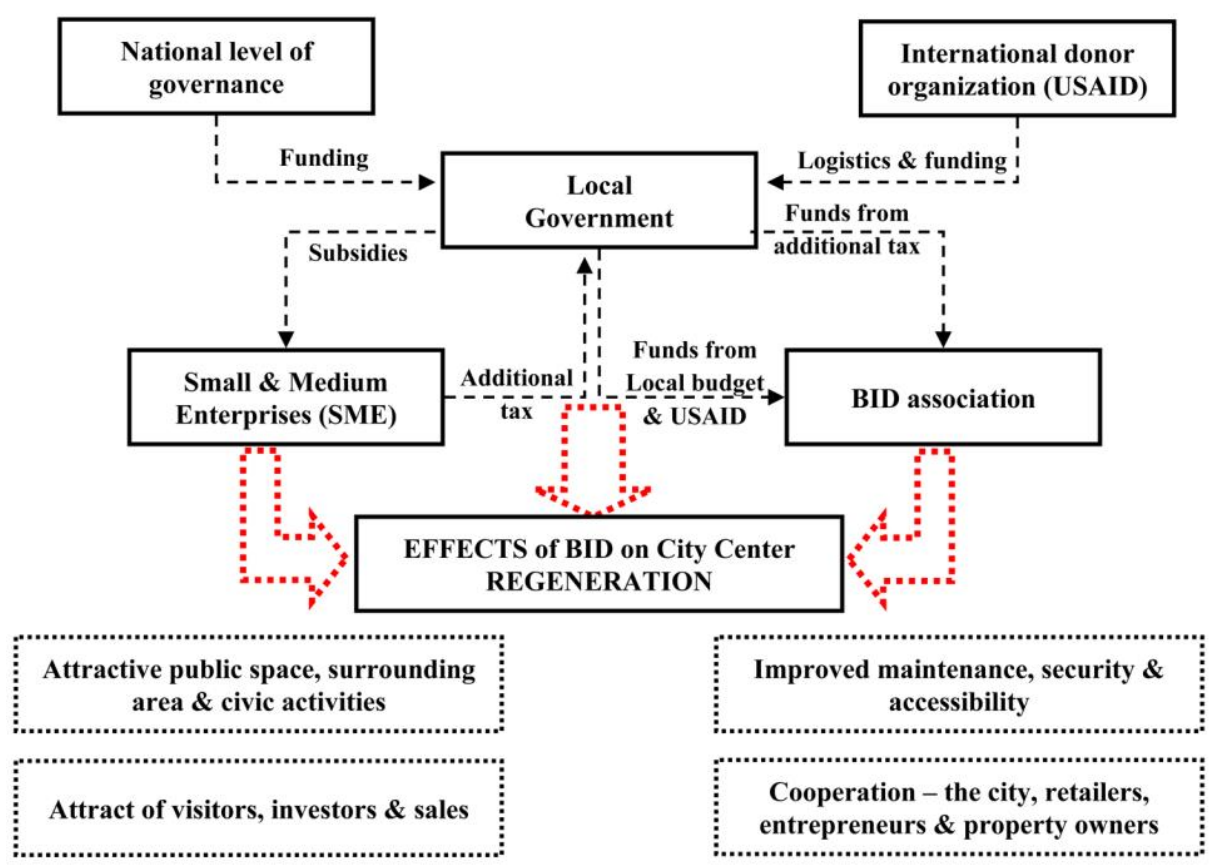

Fig. 1 Stakeholders, funding and effects of BID model for the regeneration of city centers in Serbia

\subsection{BID Zone for the regeneration of Zrenjanin commercial zone in the city centre}

The employment has increased in SME and declined in large companies in Zrenjanin from 2000 to 2002 with the ratio of $61 \%$ to $39 \%$ [16]. Due to high unemployment rate, it was important to apply some of the management instruments for stimulating local economic development for SME and BID was recognized as a tool for the regeneration of city center. BID in Zrenjanin was found as a business association in 2003 in a $700 \mathrm{~m}$ long main street (Fig. 2. left). The area consists of central pedestrian and commercial zone with the city's
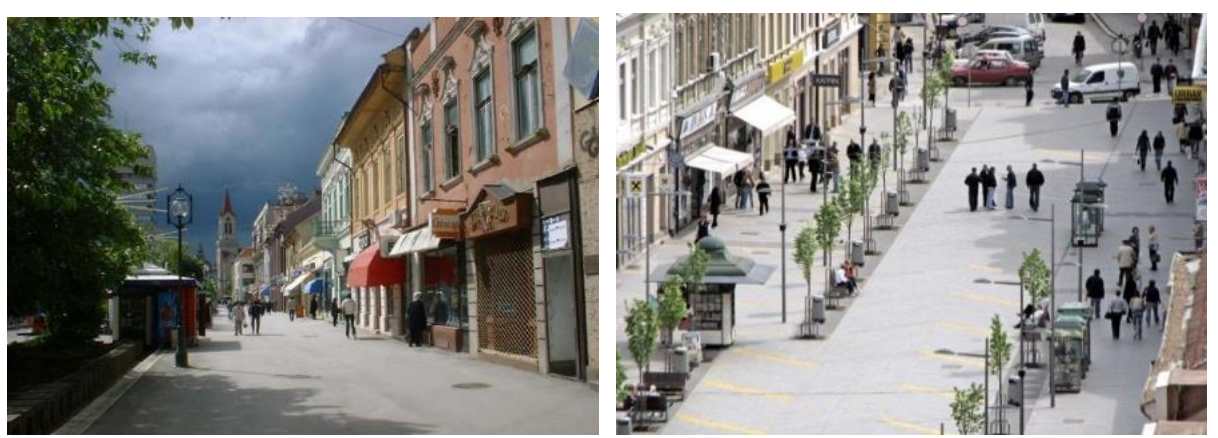

Fig. 2 Central zone in Zrenjanin before (left) (www.kudazavikend.com/8-

$\mathrm{Na} \%$ 20izlet/11753-Zrenjanin/) \& after the BID implementation (right) (www.mitarh.rs) 
main square, a few passages and galleries covering about $28,000 \mathrm{~m} 2$. The zone was spatially divided by gardens and was not seen as a unified whole, building facades were devastated and side streets passages were abandoned before the implementation of BID.

Few business owners were present for more than 60 years in the zone, while the majority came in 1990s. The zone had 220 members, including 30 retail shops, 10 banks and insurance companies, law firms, restaurants, pharmacies and small manufacturing stores in 2007 with no empty office space [10]. The municipality of Zrenjanin, the SLGRP and the USAID's CRDA, implemented by the American Development Foundation (ADF), signed an agreement in 2002 that the ADF and the municipality allocate an equal amount of funds, up to 74,000 EUR, to finance capital investment in the BID zone. It was decided during the planning process that the municipality's funding for the facades reconstruction exceed the agreed amount, and to use ADF donations to illuminate 5 public building facades in BID zone. BID funding was made by additional tax, and part of the revenue was directed to the public utility company for additional cleaning services in the BID. The annual BID budget has been projected to cca. 46,100 EUR. Reconstruction of the pedestrian zone was finished in 2008 (Fig. 2. right, Fig. 3. left) and in order to attract more visitors, BID association implemented various activities, like Days of cheese, Graduate's parades and one hour working time extension during the summer (Fig. 3. (right).
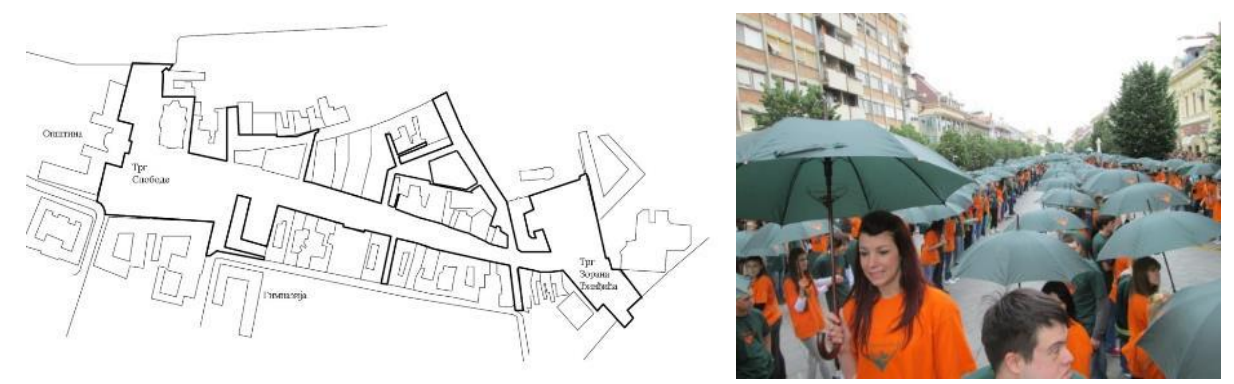

Fig. 3 Site plan of pedestrian area regeneration in 2008 (left) (by authors, 2014, based on www.mitarh.rs) \& civic activities in BID (right)

(http://ilovezrenjanin.com/aktuelno/u-centru-zrenjanina-plesalo-1300-maturanata/)

\subsection{BID Vranje for the regeneration of the city center and the Shopping mall}

Municipality of Vranje, as one of the 10 municipalities in Serbia, took part in five-year the Municipal Economic Growth Activity project (MEGA) funded by the USAID for the establishment of the BID in 2006, resulting in improvement of business conditions and creation of new jobs [17]. The Municipality opened first Business Incubator and adopted Capital investment plan increasing the number of jobs to 1,300 in 2006 . The municipality was awarded by the USAID for these results in the economic field and for the improvement of the quality of municipal services and communication with citizens, although $30 \%$ of population was living below the poverty line at the same time [18]. There was a difference in the quality of indoor and outdoor public space in Vranje city center before the implementation of BID. The problem of open public space was deteriorating street paving and lack of street furniture, while high level of crime and vandalism in the Shopping mall (Fig. 4. left \& Fig. 6. left) was the main problem resulting in the decrease of residents and SME in the city center. 

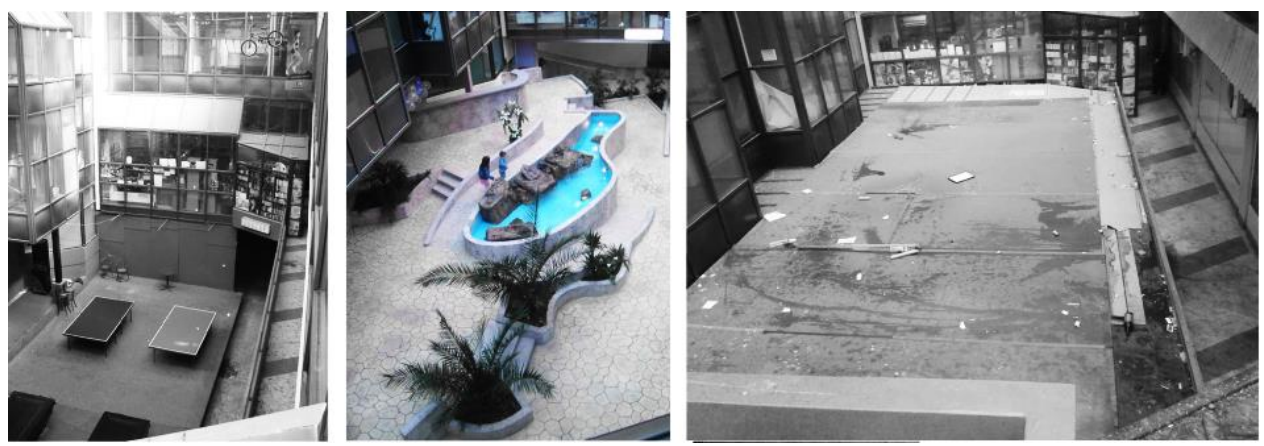

Fig. 4 Shopping mall in Vranje before BID (left); BID in 2007 (middle); BID in 2014 (right) (Photos by Noveco, Vranje 2006-2014)

It was necessary to revitalize the Shopping mall in order to create new facilities and achieve better working conditions for existing entrepreneurs (Fig. 4. middle \& Fig. 6. middle). The municipality has chosen the BID model in cooperation with the USAID as a way for the city center regeneration. The local government reform projects and adopted local economic development strategy preceded BID implementation, creating a planning framework and positive atmosphere for the BID establishment in the central city area. The first phase included the research process and interviews with shop owners and residents. The initiative was launched by the municipality through the MEGA project composed of the Association of Citizens for improved business, the Management Board, Supervisory Board and BID manager [17]. Public-private partnership was created in the second phase, and shop owners in the Shopping mall committed to a $20 \%$ additional tax. The USAID has invested cca. 419,000 EUR and the Municipality 3 time smaller amount [17]. The BID zone was planned as an extension of the pedestrian zone $400 \mathrm{~m}$ in total length (Fig. 5) after partnerships establishment, at the meeting with architects, entrepreneurs and Association of Business Improvement District representatives.

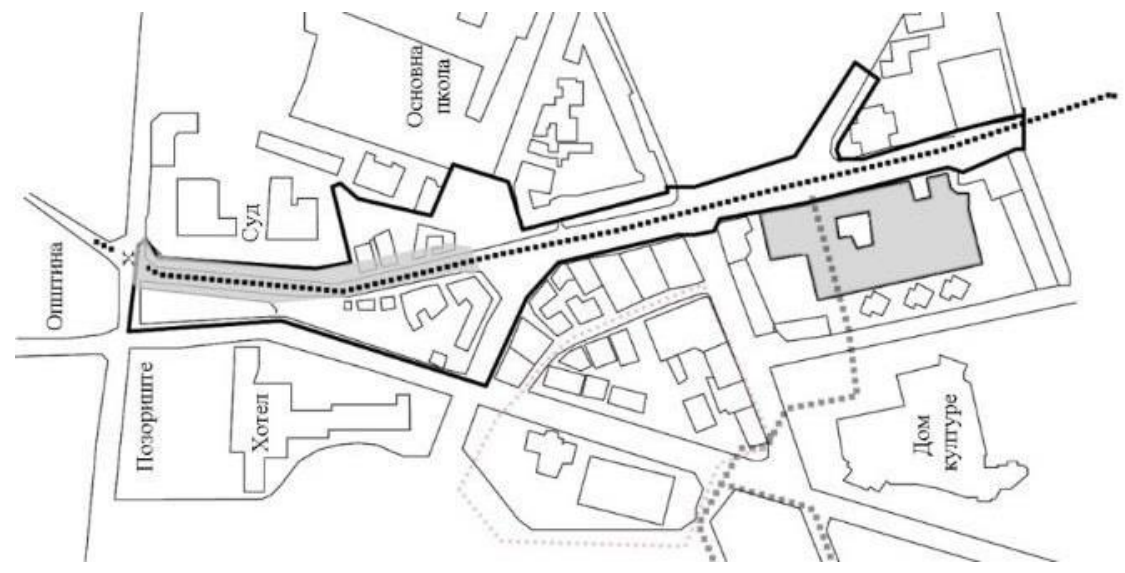

Fig. 5 Site plan of planned BID regeneration of pedestrian area in 2007 (by authors, 2014) 
Vranje-based architectural design office Noveco already located in the BID was in charge for the project design and responsible for the reconstruction of the roof, creation of a Garden center in the atrium and landscaping of common areas in the Shopping mall. Regeneration works were extended to the residential common areas in order to create a positive image of the new zone. BID was opened in March 2007 and consisted initially of 114 companies, with additional 20 new companies which joined during implementation. The BID association had rental rights and was responsible for cleaning, maintenance, security and use of public space specifically, the Garden center. More than 30\% of shops were closed in BID in 2014, mainly on upper floors of the Shopping mall. Although ground floor shops in the central pedestrian zone are still working, common space is ruined (Fig. 4. right) and Garden center privatized and turned into a night club. The high number of closed shops (Fig. 6. right) caused excessive maintenance, security and heating costs for remaining companies, and all the BID services were canceled due to the increase of additional taxes 50-60\% higher than contracted.
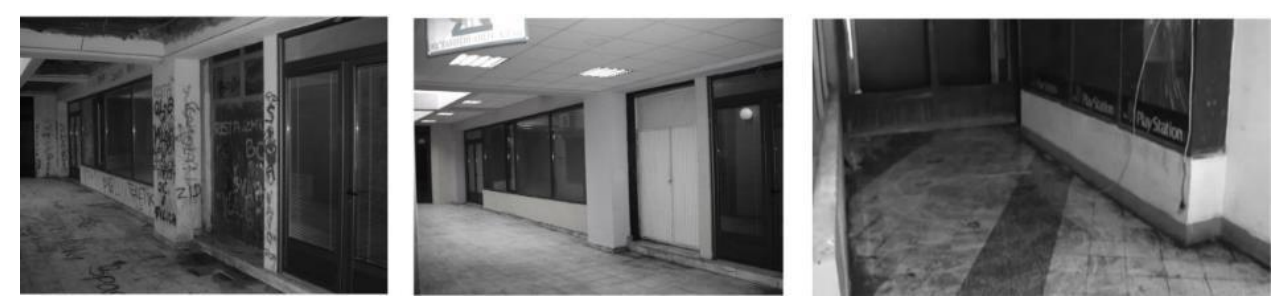

Fig. 6 Shops in Shopping mall in Vranje before BID creation (left); BID in 2007 with refurbished shops (middle); BID in 2014 with closed shops (right) (Photos by Noveco, Vranje 2006-2014).

\section{DISCUSSION AND RECOMMENDATIONS}

Analysis of the relation of management instruments use for the BID model in city center's urban regeneration in Serbia has shown the need for combination and optimization of different instruments, rather than focusing only on a particular type of instrument. Important economic, institutional, structural and other reforms on the national level of governance are needed also in transition economies for creating good business environment. We have to underline that reforms are just the framework for new models and instruments for the transformative action on urban level of governance, in which local governments and public officials play the facilitating role for the private and civic sector in general and SME and local residents in BID zones in particular.

\subsection{Regulation instruments and their influence on BID}

Criticism of the undemocratic and privatized spaces have been confirmed in the Vranje case, with main problems being unregulated legal rights of activities, duties and restrictions of BID association since the Garden center was privatized, then changed use into a night club, and after into a game room. Therefore, it is necessary to define BID association rights trough legislation in order to regulate who can be a member of BID association and with which legal rights. In Germany, for example, BID association is a construction or a private company for urban planning. Local Chamber of Commerce controls and local government 
gives legislative and expert support to BID association, and check whether it complies with the public interest and urban development plans [19]. Additionally, the agreement between the municipality and BID association should define the BID timeframe through contracts, which are currently signed for an indefinite time in the selected cases. These regulation instruments are necessary for avoiding failures, as the one in Vranje, where although BID stopped functioning after 5years, BID association holds formal rights over public spaces.

\subsection{Economic instruments in the form of subventions, funding and phasing of BID}

Since BID in Serbia is conceptualized as a combination of private company's self-help with large initial investment of international donor organizations and local government subventions as an economic instrument, it is essential to consider expenditure planning and economic evaluation of results. All shops in the Zrenjanin BID still work, but international brands have replaced local vendors, trend occurring in other Serbian cities regardless of the BID formation. All the shops on the ground level still work in Vranje, due to the location in the main street, while more than $30 \%$ of the shops on upper floors are closed and common space is ruined. It is important therefore to ensure sustainable funding during the BID implementation, after initial high public and donor subsidies, and define the minimum number of operating shops required for funding BID costs for maintenance, cleaning, heating, etc. Since city centers usually cover relatively large areas, it is necessary to plan the phasing of BID zone implementation and prioritize the most important measures for effective operation.

\subsection{Information instruments for local identity, spatial quality and creation of active public place}

BIDs were used as management instruments in the city centers regeneration in both cases creating attractive place with a positive impact on entrepreneurs. Based on our research it is evident that beside the attractive looks of BID in terms of physical improvements, it is necessary to define the activities in public space which suit the market needs and enable civic use. This was particularly evident in Vranje case with the design of Garden center without information for the shop owners about potential common use and benefits. Management instruments used for BID Zrenjanin and BID Vranje city's centre regeneration are shown in table 2.

\section{CONCLUSIONS}

The research imply that implementing BID in specific contexts as the transitional Serbian requires suitable use and combination of regulatory, economic and informational management instruments on the local level. However, management instruments use depends on the perception of problems, resources, opportunities and values in particular context. Critical factors and suggestions to be addressed when using BID as an instrument for urban regeneration are:

- Whether the initial economic instruments like subsidies from the public sector and donor agencies for the BID creation are justified and feasible economically, socially and spatially compared to other city center regeneration models and for surrounding areas? and, 
Table 1 Management instruments used for BID Zrenjanin and BID Vranje city’s centre regeneration

\begin{tabular}{|c|c|c|c|}
\hline \multicolumn{3}{|c|}{ Management instruments BID Zrenjanin } & \multirow{2}{*}{$\begin{array}{l}\text { BID Vranje } \\
\text { cca. } 18,000 \mathrm{~m}^{2}, 400 \mathrm{~m} \text { long } \\
\text { pedestrian zone, } 134 \text { shop owners }\end{array}$} \\
\hline Type & Subtype & $\begin{array}{l}\text { cca. } 28,000 \mathrm{~m}^{2}, 700 \mathrm{~m} \text { long } \\
\text { pedestrian zone, } 220 \text { shop owners }\end{array}$ & \\
\hline 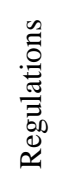 & $\begin{array}{l}\text { Influence of BID } \\
\text { contracts \& } \\
\text { management on } \\
\text { use of BID }\end{array}$ & - No negative influence & $\begin{array}{l}\text { - Privatization of public space, BID } \\
\text { organization rented Garden center } \\
\text { for night club and game room - } \\
\text { completely changed look of BID }\end{array}$ \\
\hline \multirow{3}{*}{ 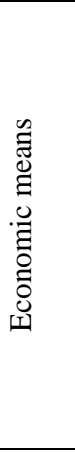 } & $\begin{array}{l}\text { Economic } \\
\text { subventions }\end{array}$ & $\begin{array}{l}\text { - Municipality - more than } 74,000 \\
\text { EUR, ADF }=74,000 \text { EUR }\end{array}$ & $\begin{array}{l}\text { - Municipality } \sim 125,000 \text { EUR, } \\
\text { USAID - } 3 \text { times more, } \sim 419,000 \\
\text { EUR }\end{array}$ \\
\hline & Phasing & $\begin{array}{l}\text { - BID established for the pedestrian } \\
\text { zone in 2003. Revitalization of } \\
\text { central pedestrian area finished in } \\
2008\end{array}$ & $\begin{array}{l}\text { - BID planned for the pedestrian } \\
\text { zone, but established only for the } \\
\text { Shopping mall in } 2007\end{array}$ \\
\hline & BID Funding & $\begin{array}{l}-20 \% \text { of additional taxes for } \\
\text { entrepreneurs in BID zone }\end{array}$ & $\begin{array}{l}-20 \% \text { of additional taxes for } \\
\text { entrepreneurs in BID zone. } \\
\text { Problem started after closure of } \\
\text { shops with the decrease in BID } \\
\text { budget. }\end{array}$ \\
\hline \multirow{3}{*}{ 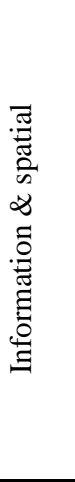 } & $\begin{array}{l}\text { Type of civic } \\
\text { activities }\end{array}$ & $\begin{array}{l}\text { - Days of Cheese, Graduation day } \\
\text { Parade, Café gardens and } \\
\text { extension of working time during } \\
\text { the summer }\end{array}$ & $\begin{array}{l}\text { - Planned Garden Center - never } \\
\text { realized due to the lack of } \\
\text { information about potential } \\
\text { benefits. No other planned } \\
\text { activities }\end{array}$ \\
\hline & $\begin{array}{l}\text { Identity \& } \\
\text { quality of public } \\
\text { spaces }\end{array}$ & $\begin{array}{l}\text { - High quality; Reconstruction of } \\
\text { facades, urban lightning, unique } \\
\text { landscaping of all public spaces }\end{array}$ & $\begin{array}{l}\text { - High quality; Roof } \\
\text { reconstruction, common areas in } \\
\text { Shopping mall \& housing areas. } \\
\text { Quality decreasing after shop } \\
\text { closure }\end{array}$ \\
\hline & $\begin{array}{l}\text { Monitoring \& } \\
\text { evaluation }\end{array}$ & $\begin{array}{l}\text { - Monitoring done/the case } \\
\text { presented as good practice for } \\
\text { other Serbian cities }\end{array}$ & - No evaluation and monitoring \\
\hline
\end{tabular}

- Are BID goals and outcomes related to other economic, social and spatial policies, including comprehensive plans for local development in providing synergies and serving the public interest?

These issues require additional local government efforts in entrepreneurial governance beyond usual cooperation among public officials and private sector in serving higher interest then only political or commercial. As Hoyt argues, private sector is willing to pay for improvements that benefit the public under the right conditions [11]. We have argued that the right conditions could be the appropriate use of management instruments, which can have positive impacts for the locality and provide social support for public official's decisions [2]. This is especially evident when benefits, such as local employment, improvements of the quality of urban public space in the BID and surrounding area are 
visible, promoted and communicated to wider society. For the successful implementation, it is necessary to provide continuous monitoring and evaluation of the BIDs effects on city center's regeneration in order to use different management instruments adjusting them to changing local needs and unpredictable market conditions. This enables a comprehensive assessment of the BID effects to the surrounding environment, perception of quality by all stakeholders, and provides a good basis for improving further BID functioning. The results should be measured continuously, with the indicators, such as: number of buyers and visitors, crime level, property values in the BID and surrounding area, number of created jobs and shop owner's revenues. We conclude that suitable use of management instruments must be tailored to each particular situation and context with specific problems and opportunities.

Acknowledgement. This paper is part of the research done within the Scientific Project TR 36035 Spatial, Environmental, Energy and Social Aspects of Development of Settlements and Climate Change, funded by the Ministry of Education, Science and Technological Development of the Republic of Serbia.

\section{REFERENCES}

1. M. Castells, The Rise of the Network Society, 2nd ed. with a new preface, vol. I, Oxford: Blackwell Publishing. (Original work published 1996), 2010.

2. U. Radosavljević, "Formation of the Urban Management Model in the Implementation of Strategic Projects", (Doctoral dissertation) University of Belgrade Faculty of Architecture, 2014.

3. D. Harvey, "From Managerialism to Entrepreneurialism: The Transformation in Urban Governance in Late Capitalism", Geografiska Annaler. Series B, Human Geography, The Roots of Geographical Change: 1973 to the Present, vol. 71, no. 1, pp. 3-17, 1989.

4. P. Healey, "Transforming Governance: Challenges of Institutional Adaptation and a New Politics of Space", European Planning Studies, vol. 14, no. 3, pp. 299-320, 2006.

5. E. Vedung, "Policy Instruments: Typologies and Theories" in Carrots, Sticks, and Sermons: Policy Instruments and Their Evaluation, M. Bemelmans-Videc, R. C. Rist and E. Vedung, Eds., Piscataway, NJ, Transaction Publishers, pp. 21-58, 1998.

6. E. H. Klijn, "New Public Management and Governance: A Comparison" in The Oxford Handbook of Governance, D. Levi-Faur, Ed., Oxford, Oxford University Press, pp. 201-214, 2012.

7. T. Bovaird and E. Löffler, "Understanding public management and governance" in Public Management and Governance, T. Bovaird and E. Löffler, Eds., London, Routledge, pp. 3-12, 2003.

8. S. Tiesdell and P. Allmendinger, "Planning Tools and Markets: Towards an Extended Conceptualisation" in Planning, Public Policy and Property Markets, D. Adams, C. Watkins and M. White, Eds., Oxford, Blackwell, pp. 56-76, 2005.

9. S. Fainstein, The City Builders. Property Development in New York and London, 1980-2000, 2nd ed., revised, Lawrence: University Press of Kansas. (Original work published 1994), 2001.

10. USAID, "How to establish a Business Improvement District (in Serbian)", 2004. [Online]. Available: www.logincee.org/file/8597/library.

11. L. Hoyt, "Planning through compulsory commercial clubs: business improvement districts", Economic Affairs, vol. 25, no. 4, pp. 24-27, 2005.

12. L. Hoyt, "The Business Improvement District: An Internationally Diffused Approach to revitalization" MIT, Cambridge, 2004.

13. M. Lloyd, J. Mccarthy, S. Mcgreal and J. Berry, "Business improvement districts, planning and urban regeneration", International Planning Studies, vol. 8, no. 4, pp. 295-321, 2003.

14. I. G. Ellen, A. E. Schwartz and I. Voicu, "The impact of Business Improvement Districts on Property Values: Evidence from New York City", Brookings-Wharton Papers on Urban Affairs, no. 8, pp. 1-31, 2007. 
15. R. Briffault, "Government for our Time? Business Improvement Districts and Urban Governance", Columbia Law Review, vol. 99, no. 2, p. 365-477, 1999.

16. Official Gazette of city of Zrenjanin, General Plan of city of Zrenjanin 2006-2026 (in Serbian), Zrenjanin: Official Gazette of city of Zrenjanin 24/08 and 17/09, 2006.

17. RTV Vranje, Aktuelno- Archival footage, E. Ostojić, Ed., RTV Vranje, 2007.

18. Ekonomist, "Vranje in 2007 - South is not necessarily sad (in Serbian)", 02 September 2007. [Online]. Available: http://www.ekapija.com/website/sr/page/124888/Ekonomist-Vranje-2007-godine-Ju\%C5\%BEnonije-nu\%C5\%BEno-tu\%C5\%BEno.

19. S. Kreutz, "Urban Improvement Districts in Germany: New legal instruments for joint proprietor activities in area development", Journal of Urban Regeneration and Renewal, vol. 2, no. 4, pp. 304-317, 2008.

\section{ZONE UNAPREĐENOG POSLOVANJA KAO MENADŽMENT INSTRUMENT ZA REGENERACIJU GRADSKIH CENTARA U SRBIJI}

Urbana regeneracija i ekonomski razvoj predstavljaju izazove neophodne za transformativne akcije u urbanom upravljanju $u$ kontekstu globalnog konkurentnog tržišta i uticaja na srpske gradove. Razumevanje tih odnosa može doprineti kreatorima politika odgovarajuću upotrebu instrumenata politika za stvaranje dobre poslovne klime u gradovima. Zone unapređenog poslovanja predstavljaju mogući model koji se koristi kao menadžment instrument za podsticanje ekonomskog razvoja, promociju grada i poboljšanje kvaliteta urbanog javnog prostora $i$ života. Rad prikazuje teorijske pristupe upotrebe instrumenata politika i daje preporuke za menadžment zona unapređenog poslovanja zasnovane na dva slučaja regeneracije gradskih centara u Srbiji. Kako bi zone unapređenog poslovanja bile koristan model za regeneraciju gradskih centara smatramo da je neophodna odgovarajuća upotreba $i$ kombinacija regulatornih, ekonomskih $i$ informacionih instrumenata menadžmenta.

Ključne reči: Zone unapređenog poslovanja, menadžment instrumenti, urbana regeneracija 